\title{
Relationship between plasma concentrations of IGF-I and clinical endometritis, and response to progesterone synchrony in dairy cows during early lactation
}

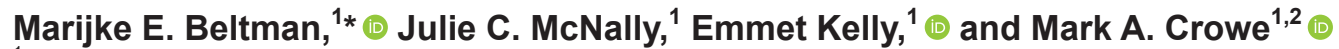 \\ ${ }^{1}$ School of Veterinary Medicine, University College Dublin, Belfield, Dublin 4, Ireland \\ ${ }^{2}$ Conway Institute for Biomolecular and Biomedical Research, University College Dublin, Belfield, Dublin 4, Ireland
}

\begin{abstract}
The first aim of this study was to evaluate the relationship between the concentrations of plasma insulinlike growth factor-I (IGF-I) in the transition period and the incidence of clinical endometritis postpartum. The second aim was to evaluate the relationship between the concentration of plasma IGF-I in the transition period and the estrous synchrony response and pregnancy rate to a controlled internal drug release (CIDR) protocol. A total of 402 dairy cows, 250 multiparous and 152 primiparous, were enrolled. A blood sample was taken from all cows 2 and 1 wk precalving and wk 1, 3, 4, and 5 postcalving for subsequent analysis of IGF-I. Vaginal discharge score as a measurement of uterine health was recorded in wk 3, 4, and 5 postcalving. Estrous cycles of all cows were synchronized on $\geq 37 \mathrm{~d}$ in milk (mean $=$ 59; range 37-93) using an 8-d CIDR protocol. All cows were scanned at 32 to $35 \mathrm{~d}$ after insemination to confirm pregnancy. Data were analyzed using Proc Mixed and Proc Logistic models in SAS (version 9.3; SAS Institute Inc., Cary, NC). Plasma IGF-I concentrations were significantly greater in the primiparous cows than in the multiparous cows, both before and after calving, and were therefore analyzed separately. In multiparous cows plasma IGF-I concentrations postcalving were significantly lower among cows with uterine infection than in those without infection, and multiparous cows with a plasma IGF-I concentration less than $40 \mathrm{ng} / \mathrm{mL}$ 1 wk after calving were 3 times more likely to suffer from a uterine infection 4 to 5 weeks postcalving (odds ratio $2.8 ; 95 \%$ confidence interval 1.0-7.6). Plasma IGF-I concentrations were significantly greater after calving in the 121 primiparous cows that exhibited estrus post-CIDR protocol (mean $125 \mathrm{ng} / \mathrm{mL}$ ) than in
\end{abstract}

Received November 28, 2019

Accepted May 13, 2020.

*Corresponding author: Marijke.beltman@ucd.ie the 25 primiparous cows that did not respond (mean 95 $\mathrm{ng} / \mathrm{mL}$ ). Multiparous cows with greater plasma IGF-I concentrations postcalving had a significantly greater chance of conceiving (mean plasma IGF-I concentration of conceiving cows $=86 \mathrm{ng} / \mathrm{mL}$; nonconceiving $=$ $70 \mathrm{ng} / \mathrm{mL}$ ). These results show an association between greater concentrations of plasma IGF-I postcalving and response to CIDR protocol in primiparous animals (mean plasma IGF-I concentration of responders = $116 \mathrm{ng} / \mathrm{mL}$; nonresponders $=95 \mathrm{ng} / \mathrm{mL}$ ). In contrast no association was detected between concentrations of plasma IGF-I in relation to the response to the CIDR protocol in multiparous cows. In conclusion, changes in circulating concentrations of plasma IGF-I early postpartum may help predict reproductive status of dairy cows.

Key words: dairy cow, clinical endometritis, CIDR synchrony, pregnancy rate

\section{INTRODUCTION}

As a consequence of high milk yield, dairy cows undergo a certain degree of negative energy balance (NEB) postpartum due to the inability to compensate for the energy demands of milk production with sufficient feed intake (Butler, 2000). An NEB leads to a decrease in insulin secretion by the pancreas, which results in lesser concentration of growth hormone receptors in the pancreas, leading to lesser concentrations of IGF-I (Pell and Bates, 1990). As such, plasma IGF-I provides a good indicator of nutritional status, as the concentration of plasma IGF-I does not fluctuate acutely either diurnally or with feeding activity (McCusker, 1998); therefore, it is likely that the IGF-I system influences events from days to weeks in advance. The plasma concentration of IGF-I in dairy cows is influenced by parity, stage of lactation (Wathes et al., 2007), and stage of ovarian cycle (Pushpakumara et al., 2003). Follicular growth is primarily controlled by gonadotropins secreted from the pituitary gland but is 
also is regulated by the production of local and systemic growth factors such as IGF-I (Mazerbourg et al., 2000; Monget et al., 2002; Spicer, 2004; Canty et al., 2006).

Plasma IGF-I is produced by the liver under the influence of growth hormone. Components of the IGF system are predominantly found in the liver but are also found in reproductive tissues, where they serve several roles, including exerting positive effects on embryo development (Wathes et al., 1998; Thatcher et al., 2003). The plasma IGF-I concentration in the periparturient period and at the time of insemination has been described as a useful predicator for reproductive performance in dairy cattle (Wiltbank et al., 2006). If a cow had plasma IGF-I of $<40 \mathrm{ng} / \mathrm{mL}$ the first week after calving, she was less likely to conceive after first service (Butler, 2000; Aungier et al., 2014). A lesser concentration of plasma IGF-I in the postpartum period was also related to the length of the interval from calving to resumption of cyclicity (Thatcher et al., 1996; Roberts et al., 1997; Crowe et al., 2014). During the early postpartum period of NEB, low-frequency LH pulses and delayed resumption of ovarian cyclicity were associated with lesser circulating IGF-I concentrations (Falkenberg et al., 2008; Crowe et al., 2014). Cows with greater plasma IGF-I concentrations in the first $2 \mathrm{wk}$ after calving had a shorter interval from parturition to commencement of luteal activity compared with those with normal concentrations (Patton et al., 2007), whereas reduced IGF-I secretion caused by NEB altered ovarian follicular estradiol production, thereby suppressing expression of estrus (Spicer et al., 1990; Crowe, 2008). Cows with NEB postpartum have alterations to the IGF-I and insulin-signaling pathways in their endometrium, which may affect the rate of tissue repair, with a possible negative effect on subsequent fertility (Wathes et al., 2011). The NEB induces decreased plasma IGF-I concentrations during the time postpartum, when the uterus must undergo extensive repair after calving (Aungier et al., 2014).

The concentrations of plasma IGF-I can therefore reflect the cow's physiological state and plays several important roles in controlling metabolism and reproduction. The objectives of the current study were twofold: (1) to evaluate the relationship between concentrations of plasma IGF-I in the transition period and incidence of clinical endometritis postpartum, and (2) to evaluate the relationship between the concentrations of plasma IGF-I in the transition period and the estrous behavior synchrony and pregnancy responses to a controlled internal drug release (CIDR) estrous synchrony protocol. The hypothesis was that cows with lesser plasma IGF-I would have an increased risk of developing clinical endometritis and a decreased response to estrous behavior synchrony treatment.

\section{MATERIALS AND METHODS}

All experimental procedures involving animals were licensed in accordance with the Cruelty to Animals Act (Ireland, 1876) and the European Community Directive 2010/63/EU, and were sanctioned by the University College Dublin Animal Research Ethics Committee.

\section{Study Animals}

This study was conducted using multiparous $(\mathrm{n}=$ $250)$ and primiparous $(\mathrm{n}=152)$ cows. The 5 commercial spring-calving dairy herds and cows used in this study were located in Leinster, Ireland, and were previously described by McNally et al. (2014). Cows of all parities (1 to 11) were represented, and cows with normal and minimal degrees of calving difficulty that calved between January and April of the study year were enrolled in the trial. All animals were housed indoors during their 60-d dry period before calving. After parturition, they remained indoors until turnout to pasture in spring, except for 1 herd that remained indoors throughout the study. Breeds represented were Holstein $(\mathrm{n}=100)$, Holstein-Friesian $(\mathrm{n}=203)$, and crossbreds $(\mathrm{n}=99)$. Median milk production of the cows enrolled was $8,261 \mathrm{~L}$ (range 4,364 to $11,359 \mathrm{~L}$ ).

\section{Experimental Procedures}

All cows enrolled in the trial were evaluated at wk -2 and -1 relative to expected calving and on wk 1, 3, 4 and 5 postcalving (Table 1). Insulin-like growth factor-I was measured at all time points, and the vaginal discharge score, as a measurement of uterine health, was recorded on wk 3, 4, and 5 postcalving. Blood samples were collected into Vacutainer tubes (Becton, Dickinson and Company, Plymouth, UK) containing lithium heparin for plasma collection. At each blood time point, plasma samples were stored at ambient temperature for a maximum of $6 \mathrm{~h}$; each sample was decanted after centrifugation for $20 \mathrm{~min}$ at $1,600 \times g$ and stored at $-20^{\circ} \mathrm{C}$ until subsequent analysis. Vaginal discharge was collected by means of a Metricheck device (Simcro Tech, Hamilton, New Zealand) that scoops discharge from the anterior vagina. The discharge was assessed as described by Williams et al. (2005). Briefly, 1 person scored the mucus for color, proportion, and volume of discharge, and a character score was assigned as follows: $0=$ no or clear mucus; $1=$ mucus containing flecks of white or off-white pus; $2=$ less than $50 \mathrm{~mL}$ of exudates, containing less than $50 \%$ white or off-white mucopurulent material; and $3=$ more than $50 \mathrm{~mL}$ of exudates, containing purulent material, usually white or yellow, but occasionally sanguineous. The vaginal 
Table 1. Timeline of key sample and data collection points relative to day of calving for dairy cows enrolled in the study ${ }^{1}$

\begin{tabular}{|c|c|c|c|c|}
\hline $\begin{array}{l}\text { Time } \\
\text { point }\end{array}$ & $\begin{array}{l}\text { Days relative } \\
\text { to calving }\end{array}$ & VDS & $\begin{array}{l}\text { Plasma } \\
\text { IGF-I }\end{array}$ & $\begin{array}{l}\text { Ultrasound } \\
\text { scan }\end{array}$ \\
\hline $\begin{array}{l}1 \\
2 \\
3 \\
4 \\
5 \\
6 \\
7\end{array}$ & $\begin{array}{l}-14 \text { to }-7 \\
-6 \text { to } 0 \\
1 \text { to } 7 \\
14 \text { to } 21 \\
22 \text { to } 28 \\
29 \text { to } 35 \\
\sim 50\end{array}$ & $\begin{array}{l} \\
\sqrt{ } \\
\sqrt{ } \\
\sqrt{ } \\
\text { CIDR insertion }\end{array}$ & $\begin{array}{l}\sqrt{ } \\
\sqrt{ } \\
\sqrt{ } \\
\sqrt{ } \\
\sqrt{ } \\
\sqrt[V]{ }\end{array}$ & $\begin{array}{l}\sqrt{ } \\
\sqrt[V]{ } \\
\sqrt{ }\end{array}$ \\
\hline
\end{tabular}

${ }^{1}$ A controlled internal drug release (CIDR) protocol was used to synchronize the estrous cycles of all cows on $\geq 37$ DIM (mean = 59, range 37-93 DIM). A vaginal discharge score (VDS) assessment was carried out at 3 time points postpartum, and plasma concentrations of IGF-I were measured at all time points.

discharge was also assessed by odor and given a score 0 for normal odor or 1 if a fetid odor was detected. The Metricheck device was cleaned and placed in dilute dilute $5 \%$ chlorhexidine gluconate solution between each cow sampled. Animals were assigned to the uterine infection (UI) classification when the vaginal discharge score was $\geq 2$ on $\mathrm{d} 23 \pm 5$ and $32 \pm 4$ postpartum (Williams et al., 2005). Body condition score was recorded at calving and on the last sampling date, using a 5 -point scale with increments of 0.25 , as described by Edmonson et al. (1989).

\section{Synchronization Treatment and AI}

Estrous cycles of all animals were synchronized using the protocol as described by McNally et al. (2014). Briefly, estrous cycles of all animals were synchronized using a CIDR (containing $1.38 \mathrm{~g}$ of progesterone; Zoetis Ireland, Dublin) intravaginally for $8 \mathrm{~d}$, with a $2.5-\mathrm{mL}$ intramuscular injection of a GnRH agonist (Receptal, MSD Animal Health, Dublin, Ireland) at the time of CIDR insertion and a 2-mL intramuscular injection of PGF2 $\alpha$ analog (Estrumate, MSD Animal Health) $1 \mathrm{~d}$ before CIDR withdrawal.

All cows were $\geq 37$ DIM (mean $=59$; range $37-93$ DIM) at the initiation of synchrony treatment, resulting in synchronized estrus or ovulation at $\geq 47$ DIM (mean $=69$; range 47-103 DIM). Cows were artificially inseminated according to the $\mathrm{AM} / \mathrm{PM}$ rule (a cow observed in standing estrus in the morning was inseminated in the afternoon of the same day, and a cow observed in standing estrus in the afternoon or evening was inseminated the following morning), following detection of estrus with the aid of tail paint. Detection of estrus was performed 4 times per 24-h period for $20 \mathrm{~min}$ (i.e., 6 -h intervals). All inseminations were performed by experienced technicians from commercial AI companies or by the herd owners and farm staff licensed by the Department of Agriculture, Food and the Marine (Dublin, Ireland), to carry out AI. Response to synchronization of the estrous cycle with the CIDR protocol was defined as a cow displaying signs of behavioral estrus.

\section{Transrectal Ultrasonography}

All ultrasound examinations were performed by 1 experienced operator, using an Ibex Lite ultrasound scanner (E.I. Medical Imaging, Loveland, CO) equipped with a $5-\mathrm{MHz}$ transrectal transducer. Cows were assigned an ultrasound reproductive tract score describing the volume and echogenicity of fluid in the uterus (Aungier et al., 2014). All cows were examined at 32 to $35 \mathrm{~d}$ after AI, using transrectal ultrasound to determine pregnancy status; visualization of a fluid-filled uterine horn and presence of a conceptus were used as positive indicators of pregnancy. The uterine, ovarian, and pregnancy findings were recorded on 3 cine loop video clips each for $4 \mathrm{~s}$ at each ultrasound examination.

\section{IGF Analysis}

Plasma IGF-I concentrations were determined using a validated double-antibody RIA after ethanol-acetoneacetic acid extraction (Beltman et al., 2010). Recombinant IGF-I (Millipore, Temecula, CA) was used as tracer and standard, anti-human IGF-I (NHPP-NIDDK AFP 4892898; National Hormone and Peptide Program, Torrance, CA; dilution 1:750,000) as the primary antibody, and anti-rabbit IgG covalently coupled to microfine cellulose particles (Sac-cel, Immunodiagnostic Systems, Boldon, UK) as the secondary antibody. The sensitivity of the IGF-I assay was $6 \mathrm{ng} / \mathrm{mL}$. Intraassay coefficient of variation (CV) for IGF-I were $16.1 \%, 11.1 \%$, and $11.2 \%$ for control serum samples containing mean concentrations of $64.5,106.9$, and $491.5 \mathrm{ng}$ IGF-I/mL, respectively. Interassay $\mathrm{CV}$ for the same control sera were $11.0 \%, 11.1 \%$, and $11.2 \%$, respectively. 


\section{Statistical Analyses}

Analysis of Continuous Data. Plasma IGF-I was classified as a continuous variable and checked for normality and homogeneity of variance both visually and analytically using histograms, quantile-quantile plots, and formal statistical tests in the UNIVARIATE procedures of SAS (version 9.3; SAS Institute Inc., Cary, NC). For variables with a non-normal distribution, the Box-Cox methodology was used to identify the most appropriate transformation. Continuous variables were analyzed using mixed models, with cow identity, lactation number, synchrony response, and pregnancy status as fixed effects, farm as random effect, and time point as a repeated effect. Biologically plausible interactions were tested for significance in the model for each dependent variable, with IGF-I concentration the independent variable and UI and estrus synchrony response dependent variables. Fixed effects $(P>0.05)$ and interactions $(P>0.10)$ not associated with the dependent variables were removed by backward elimination. All results are reported as least squares means and standard error of the means for untransformed and $95 \%$ confidence interval (CI) for log-transformed data. Main effects with $P \geq 0.05$ for the likelihood ratio chisquared statistics were considered to contribute significantly to the model and were retained; estrus response rate and pregnancy status were forced into all models.

Analysis of Binary and Ordinal Data. The occurrence of UI and healthy animals were classified as binary variables, as were response to the synchrony protocol and pregnancy status. The logit of the probability of a positive outcome for these variables was evaluated using logistic regression (PROC LOGISTIC, SAS 9.3), odds ratio (OR), and 95\% CI were calculated. Lactation number, farm, response to synchronization, and pregnancy status were included as factors in the model, and calving day of the year and DIM were included as covariates to address possible confounding effects that these factors may have had on estrous response and pregnancy status. All biologically plausible interactions were also tested in the models.

\section{RESULTS}

\section{Descriptive Statistics}

Six of the primiparous cows and thirteen of the multiparous cows were excluded for reasons including missing data or culling before AI, leaving fertility data from 146 primiparous and 237 multiparous cows. Of the primiparous cows, 71 (49\%) were diagnosed with UI postpartum (Metricheck score $\geq 2$ ), and 121 (83\%) were detected in estrus after removal of the CIDR device.
Of the 237 multiparous cows, $82(35 \%)$ were diagnosed with a UI postpartum and 201 (85\%) of the multiparous cows were detected in estrus following removal of the CIDR device. Plasma IGF-I concentrations were greater in the primiparous cows than in the multiparous cows both before and after calving $(P<0.0001$; Figure 1). When primiparous cows and multiparous cows were compared at the individual farms, the difference was still significant $(P<0.001)$. The primiparous cows were therefore separated from the multiparous animals for further data analysis. Because differences between breeds were not observed for circulating IGF-I concentration at any time points $(P \geq 0.05)$, all breeds of cows were included in the analysis $(P \geq 0.05)$. Between calving and the date of the final sample collection, 52 cows (18 primiparous and 34 multiparous) lost between 0.5 and 0.75 units of BCS, and all other cows lost $<0.5$ units of BCS. We detected no association between BCS losses and plasma IGF-I concentrations nor with UI.

\section{Plasma IGF-I Concentration in Relation to Uterine Infection}

After calving, the plasma IGF-I concentration was significantly less in cows subsequently diagnosed with UI than in those that were not. The greatest significance was seen in the first week postcalving, where cows subsequently diagnosed with UI had a plasma IGF-I concentration of $53.8 \pm 4.4 \mathrm{ng} / \mathrm{mL}$ and cows without UI had a plasma IGF-I concentration of $66.9 \pm 3.2$ $\mathrm{ng} / \mathrm{mL}(P \leq 0.005)$. Among primiparous cows, plasma

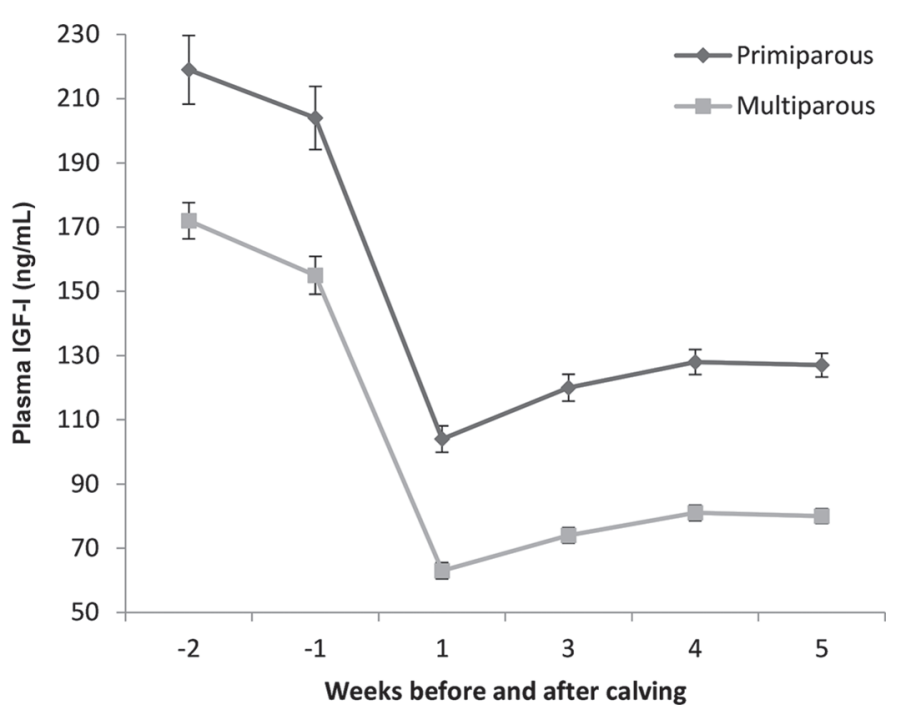

Figure 1. Changes in the mean $( \pm \mathrm{SEM})$ plasma concentrations of IGF-I (ng/mL) in 146 primiparous cows and 237 multiparous cows, from before calving to 5 wk after calving. IGF-I concentrations were significantly greater in the primiparous cows $(P<0.0001)$. 
IGF-I concentrations were not significantly different $(P \geq 0.05)$ between cows with and without UI, but a significant difference was detectable in the multiparous cows $(P \leq 0.005 ;$ Figure 2$)$
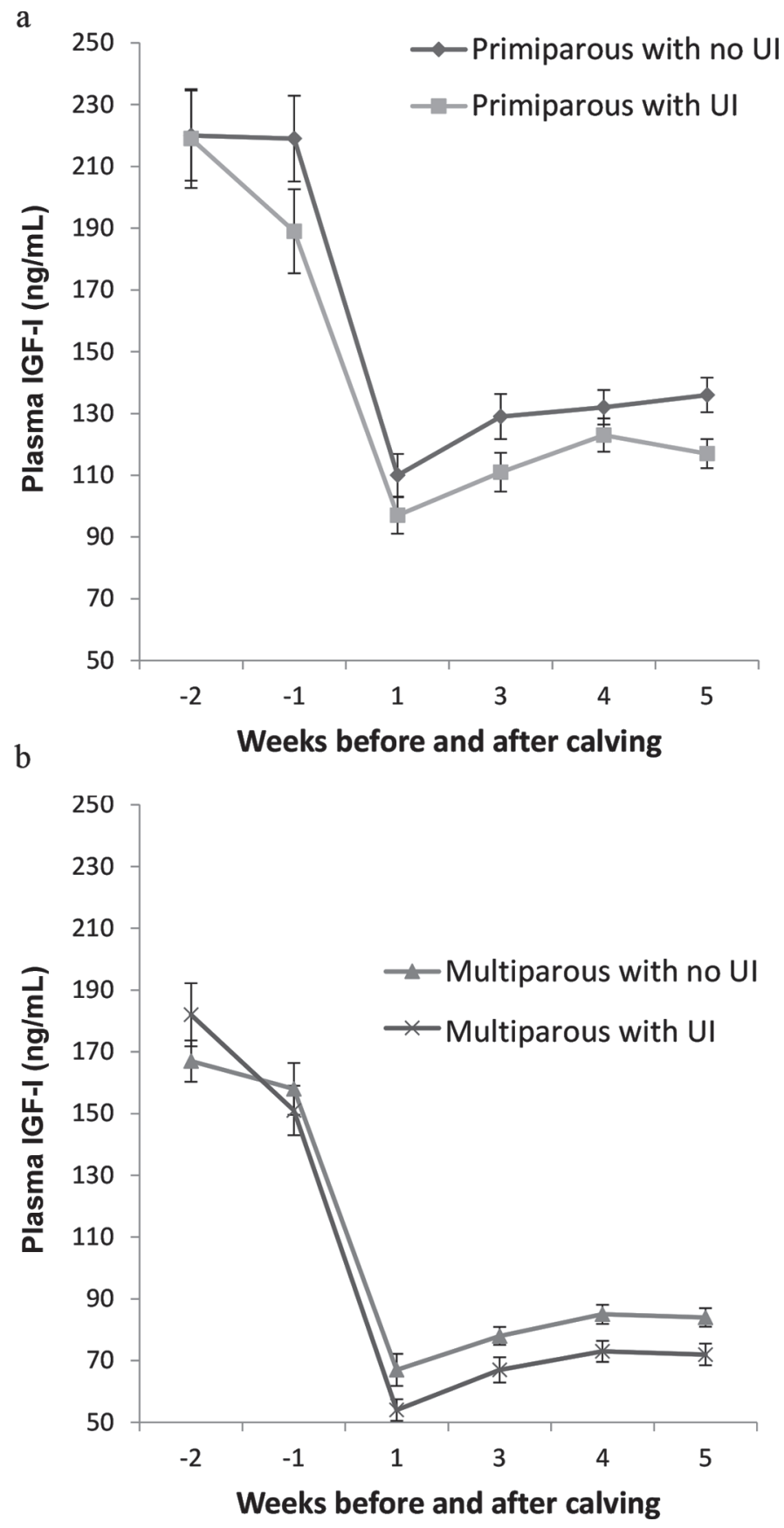

Figure 2. Changes in the mean $( \pm$ SEM) plasma concentrations of IGF-I $(\mathrm{ng} / \mathrm{mL})$ in 71 primiparous cows with uterine infection (UI) and 75 primiparous cows without UI, and in 82 multiparous cows with UI and 155 multiparous cows without UI from before calving to $5 \mathrm{wk}$ after calving. In primiparous cows, IGF-I concentrations were not significantly different $(P \geq 0.05)$ between cows with and without UI, but such differences were significant in the multiparous cows $(P \leq 0.005)$.
Of the multiparous cows that were diagnosed with UI in wk 4 or 5 postcalving, $40 \%$ had a plasma IGF-I concentration of less than $40 \mathrm{ng} / \mathrm{mL} 1$ wk after calving, whereas only $7 \%$ of cows were diagnosed with a UI when their plasma IGF-I concentration was greater than $105 \mathrm{ng} / \mathrm{mL} 1$ wk after calving. Multiparous cows with plasma IGF-I concentration less than $40 \mathrm{ng} / \mathrm{mL}$ 1 wk after calving were 3 times more likely to be diagnosed with a UI 4 or 5 wk postcalving (OR 2.8, 95\% CI 1.0 to 7.6 ), and cows with plasma IGF-I concentrations between 41 and $65 \mathrm{ng} / \mathrm{mL} 1 \mathrm{wk}$ after calving were 2 times more likely (OR 2.0, 95\% CI 0.7 to 5.5 ) than cows with a plasma IGF-I concentration $>105 \mathrm{ng} / \mathrm{mL}$.

\section{Plasma IGF-I Concentration and Response to CIDR Protocol}

Plasma IGF-I concentrations were significantly greater after calving in the 121 primiparous cows that responded to the CIDR protocol than in the 25 cows that did not respond (Figure 3). The CIDR protocol response data were then compared between the primiparous cows with plasma IGF-I concentrations of less than 60,60 to 100,101 to 140 , or $>140 \mathrm{ng} / \mathrm{mL}$ in wk 1, 3, 4, and 5 postcalving (Table 2). Primiparous cows with plasma IGF-I concentrations $>140 \mathrm{ng} / \mathrm{mL}$ in the first week postcalving were 9 times more likely to respond in estrus than animals with an IGF-I of $<60 \mathrm{ng} / \mathrm{mL}$ (OR 9.3, CI 1.8 to $6, P=0.05$ ). In the fourth week postcalving, primiparous cows with plasma IGF-I concentrations between 101 and $140 \mathrm{ng} / \mathrm{mL}$ were 3 times more likely to respond to the protocol (i.e., display estrus) than cows with concentrations $<60 \mathrm{ng} /$ $\mathrm{mL}$; cows with plasma IGF-I concentrations >140 ng/ $\mathrm{mL}$ were also 3 times more likely to respond with estrus (OR 3.2, CI 1.7 to $6.2, P=0.007$; OR 3.5, CI 1.9 to $6.4, P=0.0004)$.

Of the 121 primiparous cows that responded, 62 (51\%) were confirmed in calf 32 to $35 \mathrm{~d}$ after AI by ultrasonography. The circulation concentration of plasma IGF-I was not different between cows that were or were not in calf $(P \geq 0.05)$, except for primiparous cows in the fourth week postcalving with a plasma IGF-I concentration $>100 \mathrm{ng} / \mathrm{mL}$, which were more likely to be in calf than those with plasma IGF-I $<100 \mathrm{ng} / \mathrm{mL}(P=$ $0.003)$. In contrast, when data from all the multiparous cows were analyzed, the plasma IGF-I concentrations were not significantly different at any stage postcalving in the 201 cows that responded and the 36 that did not respond to the CIDR protocol $(P \geq 0.05)$; however, 2 wk before calving, the multiparous cows that responded to the protocol had greater plasma IGF-I concentrations $(196.8 \pm 5.8 \mathrm{ng} / \mathrm{mL})$ than the cows that did not 
Table 2. The number (percentage) of primiparous cows that responded to the controlled internal drug release (CIDR) protocol and the percentage of responders that were confirmed in calf by ultrasongraphy 32 to $35 \mathrm{~d}$ post-AI compared between primiparous cows with plasma IGF-I concentrations of less than 60, 60 to 100, 101 to 140 , or more than $140 \mathrm{ng} / \mathrm{mL}$, in wk 1, 3, 4, and 5 postcalving

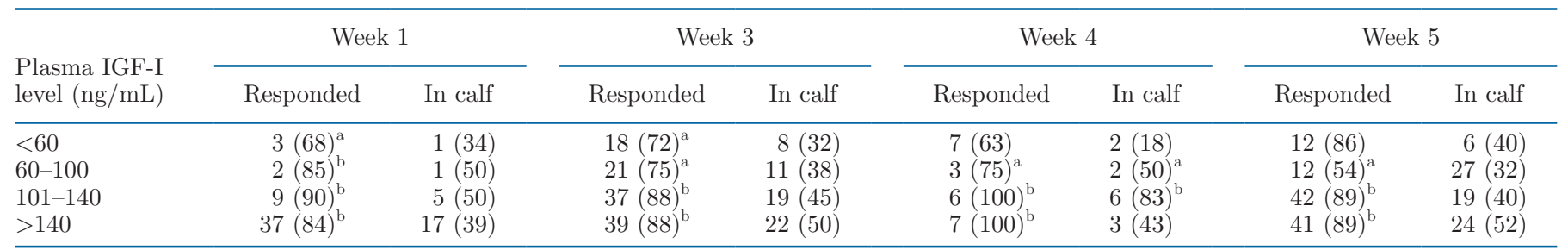

${ }^{\mathrm{a}, \mathrm{b}}$ Significance within columns, $P \leq 0.05$.

respond $(132.7 \pm 17.2 \mathrm{ng} / \mathrm{mL}, P=0.02)$. Of the 201 multiparous cows that responded to the protocol, 80 (40\%) were confirmed in calf 32 to $35 \mathrm{~d}$ after AI.

The IGF-I concentrations were a significant factor $(P=0.005)$ across the time points postcalving. Multiparous cows with greater plasma IGF-I concentrations after calving had a significantly greater chance of conceiving (Figure 4).

\section{DISCUSSION}

Various authors have reported on the important role that IGF plays in physiological and reproductive status (Butler, 2000; Wathes et al., 2007; Garnsworthy et al., 2008; Leroy et al., 2008a,b). It has a direct effect on both follicular and embryo development but also

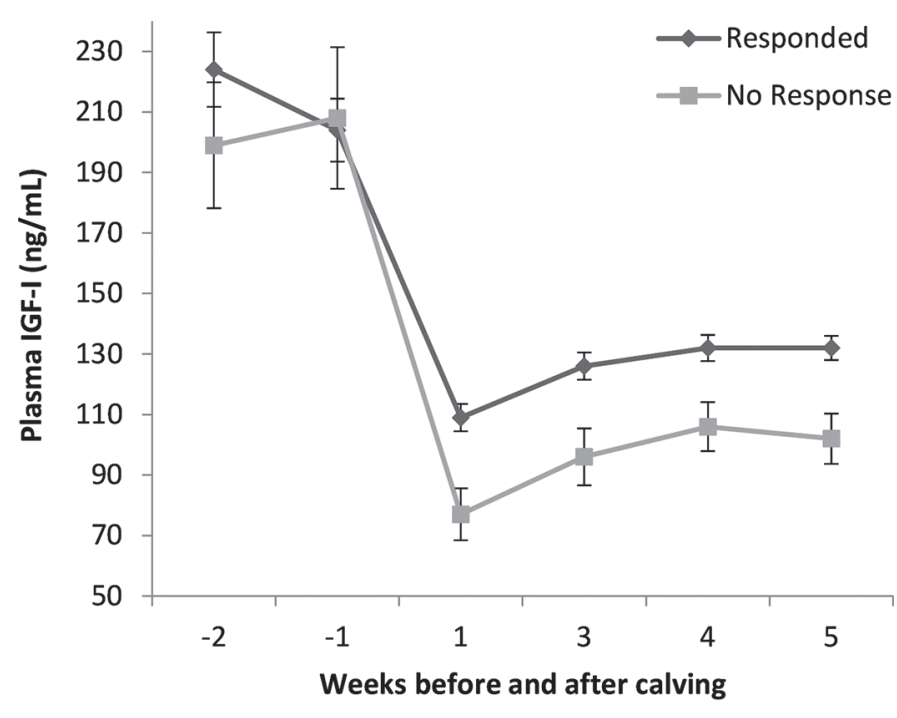

Figure 3. Changes in the mean $( \pm$ SEM $)$ plasma concentrations of IGF-I $(\mathrm{ng} / \mathrm{mL})$ in 121 primiparous cows that responded to the controlled internal drug release protocol and the 25 primiparous cows that did not response to the protocol from before calving to $5 \mathrm{wk}$ after calving. IGF-I concentrations were significantly different $(P=0.03)$ among the primiparous cows. is affected by physiological status of the cow in the postpartum period (Walsh et al., 2011).

The results of our study show that the concentrations of plasma IGF-I in primiparous cows postcalving were associated with the estrus response to the CIDR protocol in primiparous cows, but no association was found between concentrations of plasma IGF-I and UI. In contrast, among multiparous cows, no association was detected between greater concentrations of plasma IGF-I and response to the CIDR protocol, but a positive association was detected between greater plasma IGF-I concentrations and clinical endometritis postpartum.

The primiparous cows had greater plasma IGF-I concentrations both before and after calving compared with multiparous cows; however, their response to the CIDR protocol was inferior to that of the multiparous

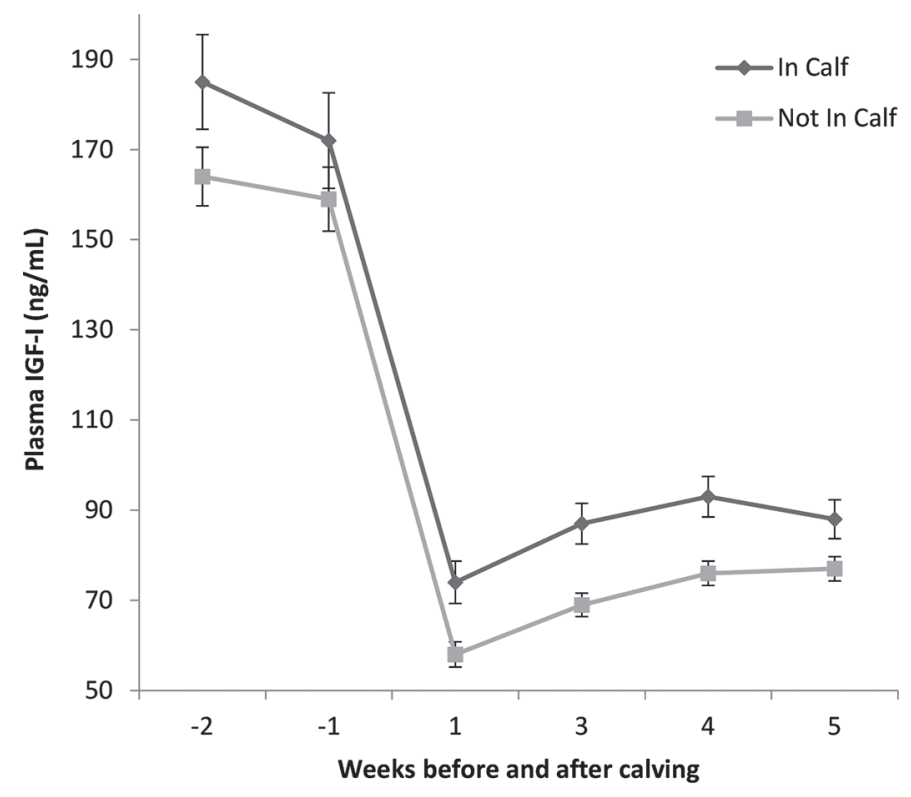

Figure 4. Changes in the mean $( \pm \mathrm{SEM})$ plasma concentrations of IGF-I $(\mathrm{ng} / \mathrm{mL})$ in 80 multiparous cows that were confirmed in calf and the 121 multiparous cows that did not conceive to the controlled internal drug release protocol from before calving to $5 \mathrm{wk}$ after calving. 
cows, suggesting that other factors may have been acting to limit their response. This effect may be related to differences in nutrient partitioning in animals that are still growing and have not yet reached physical maturity (Kerr et al., 1991). However, the concentrations of plasma IGF-I in primiparous cows postcalving had a significant effect on the response to the CIDR protocol. The positive effect of plasma IGF-I in the early postpartum period on oocyte quality could be an explanation for improved fertility of primiparous cows with greater concentrations of plasma IGF-I (Jorritsma et al., 2003). Cows with greater concentrations of plasma IGF-I responded to synchronization treatment better and became pregnant more quickly than did cows with lesser concentrations of plasma IGF-I, which was similar to the findings of Falkenberg et al. (2008). Primiparous cows have greater plasma IGF-I concentrations after calving than do multiparous cows, and an upward trend of plasma IGF-I in the early postpartum period has been discussed as a requirement for early resumption of cyclicity in dairy cows (Thatcher et al., 2006).

Although the relationship between the plasma IGF-I concentrations after calving and response to the protocol was less pronounced with multiparous than with primiparous cows, the multiparous cows with lesser plasma IGF-I concentrations were nevertheless less likely to conceive. A lesser percentage of multiparous animals were confirmed in calf after the CIDR protocol compared with primiparous cows (40\% vs. 51\%); therefore, the concentrations of plasma IGF-I after calving had a significant role in determining whether the multiparous cows would be confirmed in calf. Cows in early lactation are prone to NEB, which arises from high milk energy output and relatively less feed intake, and cows with NEB are known to have a longer interval to first ovulation (Kruip et al., 1998; Beever, 2006). No association was found between the concentrations of plasma IGF-I postcalving and the response to the protocol within multiparous cows, but because the concentrations were less than in primiparous cows, the multiparous cows may have suffered NEB. The association between BCS loss in early lactation and subsequent reproductive performance is now well established (Buckley et al., 2003; Shrestha et al., 2005). During the period of declining NEB, LH pulses are suppressed, and dominant follicles that develop have a decreased chance of producing sufficient estradiol to induce a preovulatory gonadotropin surge (Beam and Butler, 1999; Crowe, 2008). Poor energy status is also known to have a deleterious effect on oocytes developing within the ovary, thus reducing their chance of being fertilized successfully (Snijders et al., 2000). Lesser plasma IGF-I concentrations may have already affected the oocytes, and the growth of the embryo may also be compromised (Leroy et al., 2008a; Beltman et al., 2010).

In the present study, multiparous cows without UI had greater circulating IGF-I concentrations than cows with UI, supporting the well-established relationship between NEB and risk of UI (Dubuc et al., 2010). An antagonistic relationship between the proinflammatory cytokines and plasma IGF-I generally occurs during disease conditions (Kasimanickam et al., 2013). It is plausible that poor energy status indicated by lesser IGF-I may therefore inhibit the ability of cows to raise an effective immune response to the bacterial challenge after calving and also delay the general repair process within the endometrium, thus prolonging uterine involution. In comparison, cows with more favorable energy balance, as evidenced by greater plasma IGFI concentrations, may undergo uterine involution at a more rapid rate. In support of this, plasma IGF-I may antagonize proinflammatory activity by decreasing expression of the IL receptor and via suppression of cytokine-signaling proteins (Kasimanickam et al., 2013).

In conclusion, the findings of this study suggest that changes in circulating concentrations of plasma IGF-I early postpartum may help predict reproductive status in dairy cattle. This study identified that greater circulating concentrations of plasma IGF-I in wk 1 after calving could be a prognostic biomarker for primiparous cows and their response to a progesterone CIDR protocol when a cowside test becomes available in the future. Among the multiparous cows, those with greater plasma IGF-I were more likely to be confirmed in calf after the CIDR protocol than multiparous cows with lesser plasma IGF-I in the same time period.

\section{ACKNOWLEDGMENTS}

This study was funded by Science Foundation Ireland (Dublin; grant number 07/SRC/B1156) and Pfizer Animal Health (now Zoetis, Dublin, Ireland). The authors thank the staff and owners of the farms involved in the trial for their support and assistance. Special thanks go to the University College Dublin (UCD) Reproductive Biology Research Cluster team for their help during the fieldwork. Special thanks also go to Fiona Carter of UCD Lyons Research Farm (Co. Kildare, Ireland), and the staff in the hormone assay laboratory (UCD Veterinary Sciences Centre) for their expert technical assistance. The authors acknowledge A. F. Parlow of the National Hormone and Peptide Program (NHPP, Torrance, CA) of the National Institutes of Health for provision of the IGF-I primary antibody [anti-human IGF-I (NHPP167 NIDDK AFP 4892898)]. Finally, the 
authors thank Sean Ramsbottom and Dan Ryan (ReproDoc Ltd., Cullenagh, Fermoy, Co. Cork, Ireland) for their on-farm technical assistance. The authors have not stated any conflicts of interest.

\section{REFERENCES}

Aungier, S. P., J. F. Roche, M. G. Diskin, and M. A. Crowe. 2014 Risk factors that affect reproductive target achievement in fertile dairy cows. J. Dairy Sci. 97:3472-3487. https://doi.org/10.3168/ jds.2013-7404.

Beam, S. W., and W. R. Butler. 1999. Effects of energy balance on follicular development and first ovulation in postpartum dairy cows. J. Reprod. Fertil. Suppl. 54:411-424.

Beever, D. E. 2006. The impact of controlled nutrition during the dry period on dairy cow health, fertility and performance. Anim. Reprod. Sci. 96:212-226. https://doi.org/10.1016/j.anireprosci.2006 .08 .002 .

Beltman, M. E., N. Forde, P. Furney, F. Carter, J. F. Roche, P. Lonergan, and M. A. Crowe. 2010. Characterisation of endometrial gene expression and metabolic parameters in beef heifers yielding viable or non-viable embryos on Day 7 after insemination. Reprod. Fertil. Dev. 22:987-999. https://doi.org/10.1071/RD09302.

Buckley, F., K. O'Sullivan, J. F. Mee, R. D. Evans, and P. Dillon. 2003. Relationships among milk yield, body condition, cow weight, and reproduction in spring-calved Holstein-Friesians. J. Dairy Sci. 86:2308-2319. https://doi.org/10.3168/jds.S0022-0302(03)73823 -5 .

Butler, W. R. 2000. Nutritional interactions with reproductive performance in dairy cattle. Anim. Reprod. Sci. 60-61:449-457. https:// doi.org/10.1016/S0378-4320(00)00076-2.

Canty, M. J., M. P. Boland, A. C. O. Evans, and M. A. Crowe. 2006. Alterations in follicular IGFBP mRNA expression and follicular fluid IGFBP concentrations during the first follicle wave in beef heifers. Anim. Reprod. Sci. 93:199-217. https://doi.org/10.1016/j .anireprosci.2005.06.033.

Crowe, M. A. 2008. Resumption of ovarian cyclicity in post-partum beef and dairy cows. Reprod. Domest. Anim. 43(Suppl. 5):20-28. https://doi.org/10.1111/j.1439-0531.2008.01210.x.

Crowe, M. A., M. G. Diskin, and E. J. Williams. 2014. Parturition to resumption of ovarian cyclicity: Comparative aspects of beef and dairy cows. Animal 8(Suppl. s1):40-53.

Dubuc, J., T. F. Duffield, K. E. Leslie, J. S. Walton, and S. J. LeBlanc. 2010. Risk factors for postpartum uterine diseases in dairy cows. J. Dairy Sci. 93:5764-5771. https://doi.org/10.3168/jds.2010-3429.

Edmonson, A. J., I. J. Lean, L. D. Weaver, T. Farver, and G. Webster. 1989. A body condition scoring chart for Holstein dairy cows. J. Dairy Sci. 72:68-78. https://doi.org/10.3168/jds.S0022 -0302(89)79081-0.

Falkenberg, U., J. Haertel, K. Rotter, M. Iwersen, G. Arndt, and W. Heuwieser. 2008. Relationships between the concentration of insulin-like growth factor-1 in serum in dairy cows in early lactation and reproductive performance and milk yield. J. Dairy Sci. 91:3862-3868. https://doi.org/10.3168/jds.2007-0887.

Garnsworthy, P. C., A. Lock, G. E. Mann, K. D. Sinclair, and R. Webb. 2008. Nutrition, metabolism, and fertility in dairy cows: 1. Dietary energy source and ovarian function. J. Dairy Sci. 91:38143823. https://doi.org/10.3168/jds.2008-1031.

Jorritsma, R., T. Wensing, T. A. Kruip, P. L. Vos, and J. P. Noordhuizen. 2003. Metabolic changes in early lactation and impaired reproductive performance in dairy cows. Vet. Res. 34:11-26. https: //doi.org/10.1051/vetres:2002054.

Kasimanickam, R. K., V. R. Kasimanickam, J. R. Olsen, E. J. Jeffress, D. A. Moore, and J. P. Kastelic. 2013. Associations among serum pro- and anti-inflammatory cytokines, metabolic mediators, body condition, and uterine disease in postpartum dairy cows. Reprod. Biol. Endocrinol. 11:103. https://doi.org/10.1186/1477-7827-11 -103 .
Kerr, D. E., J. G. Manns, B. Laarveld, and M. I. Fehr. 1991. Profiles of serum IGF-I concentrations in calves from birth to eighteen months of age and in cows throughout the lactation cycle. Can. J. Anim. Sci. 71:695-705. https://doi.org/10.4141/cjas91-085.

Kruip, T. A. M., G. A. L. Meijer, T. Rukkwamsuk, and T. Wensing. 1998. Effects of feed in the dry period on fertility of dairy cows post partum. Reprod. Domest. Anim. 33:165-168. https://doi.org/ 10.1111/j.1439-0531.1998.tb01336.x.

Leroy, J. L. M. R., G. Opsomer, A. Van Soom, I. G. F. Goovaerts, and P. E. J. Bols. 2008a. Reduced fertility in high-yielding dairy cows: Are the oocyte and embryo in danger? Part I: The importance of negative energy balance and altered corpus luteum function to the reduction of oocyte and embryo quality in high-yielding dairy cows. Reprod. Domest. Anim. 43:612-622. https://doi.org/ 10.1111/j.1439-0531.2007.00960.x.

Leroy, J. L. M. R., A. Van Soom, G. Opsomer, I. G. F. Goovaerts, and P. E. J. Bols. 2008b. Reduced fertility in high-yielding dairy cows: Are the oocyte and embryo in danger? Part II: Mechanisms linking nutrition and reduced oocyte and embryo quality in high-yielding dairy cows. Reprod. Domest. Anim. 43:623-632. https://doi.org/ 10.1111/j.1439-0531.2007.00961.x.

Mazerbourg, S., J. Zapf, R. S. Bar, D. R. Brigstock, and P. Monget. 2000. Insulin-like growth factor (IGF)-binding protein-4 proteolytic degradation in bovine, equine, and porcine preovulatory follicles: Regulation by IGFs and heparin-binding domain-containing peptides. Biol. Reprod. 63:390-400. https://doi.org/10.1095/ biolreprod63.2.390.

McCusker, R. H. 1998. Controlling insulin-like growth factor activity and the modulation of insulin-like growth factor binding protein and receptor binding. J. Dairy Sci. 81:1790-1800. https://doi.org/ 10.3168/jds.S0022-0302(98)75748-0.

McNally, J. C., M. A. Crowe, J. F. Roche, and M. E. Beltman. 2014. Effects of physiological and/or disease status on the response of postpartum dairy cows to synchronization of estrus using an intravaginal progesterone device. Theriogenology 82:1263-1272. https:/ /doi.org/10.1016/j.theriogenology.2014.08.006.

Monget, P., S. Fabre, P. Mulsant, F. Lecerf, J.-M. Elsen, S. Mazerbourg, C. Pisselet, and D. Monniaux. 2002. Regulation of ovarian folliculogenesis by IGF and BMP system in domestic animals. Domest. Anim. Endocrinol. 23:139-154. https://doi.org/10.1016/ S0739-7240(02)00152-2.

Patton, J., D. A. Kenny, S. McNamara, J. F. Mee, F. P. O’Mara, M. G. Diskin, and J. J. Murphy. 2007. Relationships among milk production, energy balance, plasma analytes, and reproduction in Holstein-Friesian cows. J. Dairy Sci. 90:649-658. https://doi.org/ 10.3168/jds.S0022-0302(07)71547-3.

Pell, J. M., and P. C. Bates. 1990. The nutritional regulation of growth hormone action. Nutr. Res. Rev. 3:163-192. https://doi.org/10 $.1079 /$ NRR19900011.

Pushpakumara, P. G., N. H. Gardner, C. K. Reynolds, D. E. Beever, and D. C. Wathes. 2003. Relationships between transition period diet, metabolic parameters and fertility in lactating dairy cows. Theriogenology 60:1165-1185. https://doi.org/10.1016/S0093 -691X(03)00119-5.

Roberts, A. J., R. A. Nugent 3rd, J. Klindt, and T. G. Jenkins. 1997. Circulating insulin-like growth factor I, insulin-like growth factor binding proteins, growth hormone, and resumption of estrus in postpartum cows subjected to dietary energy restriction. J. Anim. Sci. 75:1909-1917. https://doi.org/10.2527/1997.7571909x.

Shrestha, H. K., T. Nakao, T. Suzuki, M. Akita, and T. Higaki. 2005. Relationships between body condition score, body weight, and some nutritional parameters in plasma and resumption of ovarian cyclicity postpartum during pre-service period in high-producing dairy cows in a subtropical region in Japan. Theriogenology 64:855-866. https://doi.org/10.1016/j.theriogenology.2004.12.007.

Snijders, S. E. M., P. Dillon, D. O'Callaghan, and M. P. Boland. 2000. Effect of genetic merit, milk yield, body condition and lactation number on in vitro oocyte development in dairy cows. Theriogenology 53:981-989. https://doi.org/10.1016/S0093-691X(00)00244-2. 
Spicer, L. J. 2004. Proteolytic degradation of insulin-like growth factor binding proteins by ovarian follicles: A control mechanism for selection of dominant follicles. Biol. Reprod. 70:1223-1230. https:/ /doi.org/10.1095/biolreprod.103.021006.

Spicer, L. J., W. B. Tucker, and G. D. Adams. 1990. Insulin-like growth factor-I in dairy cows: Relationships among energy balance, body condition, ovarian activity, and estrous behavior. J. Dairy Sci. 73:929-937. https://doi.org/10.3168/jds.S0022-0302(90)78749-8.

Thatcher, W. W., T. R. Bilby, J. A. Bartolome, F. Silvestre, C. R. Staples, and J. E. P. Santos. 2006. Strategies for improving fertility in the modern dairy cow. Theriogenology 65:30-44. https://doi .org/10.1016/j.theriogenology.2005.10.004.

Thatcher, W. W., R. L. de la Sota, E. J. Schmitt, T. C. Diaz, L. Badinga, F. A. Simmen, C. R. Staples, and M. Drost. 1996. Control and management of ovarian follicles in cattle to optimize fertility. Reprod. Fertil. Dev. 8:203-217. https://doi.org/10.1071/ RD9960203.

Thatcher, W. W., A. Guzeloglu, A. Meikle, S. Kamimura, T. R. Bilby, A. A. Kowalski, L. Badinga, R. Pershing, J. A. Bartolome, and J. E. Santos. 2003. Regulation of embryo survival in cattle. Reprod. Suppl. 61:253-266.

Walsh, S. W., E. J. Williams, and A. C. O. Evans. 2011. A review of the causes of poor fertility in high milk producing dairy cows. Anim. Reprod. Sci. 123:127-138. https://doi.org/10.1016/j .anireprosci.2010.12.001.

Wathes, D. C., Z. Cheng, M. A. Fenwick, R. Fitzpatrick, and J. Patton. 2011. Influence of energy balance on the somatotrophic axis and matrix metalloproteinase expression in the endometrium of the postpartum dairy cow. Reproduction 141:269-281. https://doi .org/10.1530/REP-10-0177.

Wathes, D. C., M. Fenwick, Z. Cheng, N. Bourne, S. Llewellyn, D. G. Morris, D. Kenny, J. Murphy, and R. Fitzpatrick. 2007. Influence of negative energy balance on cyclicity and fertility in the high producing dairy cow. Theriogenology 68(Suppl. 1):S232-S241.

Wathes, D. C., T. S. Reynolds, R. S. Robinson, and K. R. Stevenson. 1998. Role of the insulin-like growth factor system in uterine function and placental development in ruminants. J. Dairy Sci. 81:1778-1789. https://doi.org/10.3168/jds.S0022-0302(98)75747 $-9$.

Williams, E. J., D. P. Fischer, D. U. Pfeiffer, G. C. W. England, D. E. Noakes, H. Dobson, and I. M. Sheldon. 2005. Clinical evaluation of postpartum vaginal mucus reflects uterine bacterial infection and the immune response in cattle. Theriogenology 63:102-117. https: //doi.org/10.1016/j.theriogenology.2004.03.017.

Wiltbank, M., H. Lopez, R. Sartori, S. Sangsritavong, and A. Gumen. 2006. Changes in reproductive physiology of lactating dairy cows due to elevated steroid metabolism. Theriogenology 65:17-29. https://doi.org/10.1016/j.theriogenology.2005.10.003.

\section{ORCIDS}

Marijke E. Beltman ( https://orcid.org/0000-0002-1598-4845

Emmet Kelly @ https://orcid.org/0000-0001-5145-860X

Mark A. Crowe @ https://orcid.org/0000-0003-1999-815X 